\title{
Experimental demonstration of the pathogenicity of a frog virus, Bohle iridovirus, for a fish species, barramundi Lates calcarifer
}

\author{
N. J. G. Moody, L. Owens \\ Department of Biomedical and Tropical Veterinary Science, James Cook University of North Queensland, 4811 Townsville, \\ Australia
}

\begin{abstract}
Experimental infections indicate that Bohle iridovirus, a Ranavirus, is pathogenic for barramundi Lates calcarifer Bloch. Mortalities after bath-exposure or inoculation of barramundi in both freshwater and seawater were $100 \%$. Symptoms of inoculated barramundi held in seawater and freshwater and bath-exposed barramundi in freshwater included cessation of feeding, shivering, loss of muscle coordination, spiral and often erratic swimming and decreased ventilation. Just prior to death, the fish were incapable of any movement. In bath-exposed barramundi held in seawater, no symptoms were observed before death. The infection was characterised by focal to diffuse necrosis of the haematopoietic tissue of the kidney and spleen. In several BIV-infected barramundi, focal necrosis occurred in the liver. In bath-exposed and inoculated barramundi, BIV was isolated on BF2 cell monolayers from muscle, liver, kidney and spleen tissues, with recovery rates of $72.5,58.5,17.7$ and $17.7 \%$ respectively. This is the first time that a virus isolated from a frog has been shown to cause mortalities in a fish species.
\end{abstract}

KEY WORDS: Iridovirus $\cdot$ Pathogenicity $\cdot$ Lates

\section{INTRODUCTION}

The Bohle iridovirus (BIV) was isolated from metamorphs of the ornate burrowing frog Lymnodynastes ornatus during a routine study on the pathogens of the cane toad Bufo marinus. The metamorphs were collected from a temporary pond at Bohle, a suburb of Townsville, Queensland, Australia, and the virus was isolated after investigations into the deaths of the frogs during, or soon after, metamorphosis (Speare \& Smith 1992).

R. Speare (Anton Breinl Centre for Tropical Health and Medicine, Townsville, Queensland, Australia, pers. comm.) reported that BIV was highly pathogenic to tadpoles and juveniles of Lymnodynastes ornatus and Bufo marinus and to adults of $B$. marinus, where it caused hepatic, renal and pulmonary necroses and haemorrhages. BIV was experimentally spread via infected food or by subcutaneous injection and was then transferred from infected to uninfected toads via faeces or by a common water source (Speare pers. comm.). This virus has also been shown to cause mortality in tadpoles of the green tree frog Litoria caurulea.

A natural source for the virus, other than the original isolation, has not been discovered (Speare pers. comm.) and no additional outbreaks have been reported. BIV is only the second endemic iridovirus isolated from vertebrates in Australia (Speare pers. comm.), the first being epizootic haematopoietic necrosis virus (EHNV), isolated from redfin perch Perca fluviatilis in Victoria (Langdon et al. 1986).

BIV strongly resembles EHNV in morphology, ultrastructure, viral morphogenesis, multiplication in certain cell lines and cross-reaction of antisera. However, differences between the viruses include size, cell susceptibility in vitro, cytopathic effect, protein profiles and DNA restriction endonuclease cleavage patterns (Hengstberger et al. 1993). BIV also failed to multiply or produce infection in rainbow trout Onchorhynchus mykiss, a fish species susceptible to EHNV (Langdon 
et al. 1988). These facts have led to the conclusion that BIV and EHNV are closely related, but distinct, iridoviruses (Hengstberger et al. 1993).

Given the close relationship between BIV and EHNV, it may be possible for EHNV to infect amphibians and for BIV to infect fishes. The latter forms the basis for the experiments reported in this paper, where barramundi Lates calcarifer Bloch, a commercially and recreationally important fish species in Australia and Asia, were experimentally infected with the Bohle iridovirus,

\section{MATERIALS AND METHODS}

Barramundi stock maintenance. Barramundi tingerlings were obtained from the Queensland Department of Primary Industries' Northern Fisheries Centre in Caims and ranged in size from 9.5 to $16.0 \mathrm{~cm}$. Prior to experiments, the fish were maintained in a $1000 \mathrm{l}$ plastic holding tank (Reln Pty. Ltd, Sydney, Australia) filled with recirculating, aerated seawater (35 ppt). Salinity, temperature, ammonia and nitrite levels were monitored each week.

Power filters (Fluval 403, Rolf C. Hagan, Montreal, $P Q$, Canada), filled with coral rubble, activated carbon and filter wool, were used to filter and recirculate the water. Immersible automatic water heaters (Rena, France) were used to maintain a water temperature of $29^{\circ} \mathrm{C}$ in each experimental and stock aquaria. Barramundi were fed dry fish pellets.

Before use in experiments, the fish were allowed to acclimatise to their surroundings over a $7 \mathrm{~d}$ period and during experiments the barramundi were maintained at a density no greater than 0.25 fish $\mathrm{l}^{-1}$. Water quality parameters and general fish health were monitored daily.

Culture of BF2 cells. Bluegill fry (BF2) (Wolf et al. 1966) cell monolayers (passage \#45 to \#160) were cultured for use in the propagation, titration and isolation of virus. Cells were grown in 150 or $25 \mathrm{~cm}^{2}$ plastic culture flasks (Corning Glass Works, USA) using Dulbecco's Modified Eagle's Media (DMEM), supplemented with $5 \%$ foetal bovine serum and $5 \%$ calf serum. All cell cultures were incubated at $26^{\circ} \mathrm{C}$ and cell number determined with a haemocytometer.

Bohle iridovirus culture. The Bohle iridovirus employed was isolated from the ornate burrowing frog Lymnodynastes ornatus by R. Speare and was cultured in BF2 cells in $150 \mathrm{~cm}^{2}$ plastic culture flasks. Cell monolayers were infected with 3 to $4 \mathrm{ml}$ of clarified BIV. After $1 \mathrm{~h}$, DMEM containing $10 \%$ calf serum was added and the flasks were incubated at $26^{\circ} \mathrm{C}$. When the cell monolayer had been completely destroyed by the virus ( 2 to $3 \mathrm{~d}$ ), the media and cells were frozen and thawed 3 times and stored at $-66^{\circ} \mathrm{C}$.

Prior to use, the virus was assayed and titres were calculated (Reed \& Muench 1938) and expressed as $10^{x}$ $\mathrm{TCID}_{50} \mathrm{ml}^{-1}$ (50\% tissue culture infective dose). The titre of the viral stock used in the experiments was $10^{5}$ $\mathrm{TCID}_{50} \mathrm{mll}^{-1}$. Dilutions of BIV were made in DMEM for inoculation experiments and in the aquarium water for bath exposure experiments.

Inoculation of barramundi with Bohle iridovirus. Ten barramundi, held in freshwater, were inoculated intraperitoneally and intramuscularly with $0.2 \mathrm{ml} 10^{5}$ $\mathrm{TCID}_{50} \mathrm{ml}^{-1}$ of BIV at each site. Another 10 freshwater barramundi were similarly inoculated with $0.2 \mathrm{ml}$ DMEM as a placebo. The same protocol was followed using barramundi from the seawater tank (35 ppt). Barramundi were maintained in separate aquaria and monitored daily for any signs of illness.

Bath exposure of barramundi with Bohle iridovirus. Ten barramundi were placed in an aquarium containing $5 \mathrm{l}$ of freshwater and 10 were placed in an aquarium filled with $5 \mathrm{l}$ of seawater. Fifty $\mathrm{ml}$ of $10^{5} \mathrm{TCID}_{50}$ $\mathrm{ml}^{-1} \mathrm{BIV}$ was added to the water in each tank resulting in a viral concentration of $10^{3}$ TCID $_{50} \mathrm{ml}^{-1}$. The fish were left in the small volume of water for $1 \mathrm{~h}$. On each following hour, the water level in the tanks was doubled until the tanks had been filled to the required level. This resulted in a final concentration in each tank of $10 \mathrm{TCID}_{50} \mathrm{ml}^{-1}$.

In order to determine the minimum infective dose of the virus in seawater, 4 aquaria had BIV added to them at the following final concentrations: $10^{2}, 10^{1}$, $10^{0.5}$ and $10^{0} \mathrm{TCID}_{50} \mathrm{ml}^{-1}$. Four barramundi were placed in each tank and any symptoms and mortalities were noted

Freshwater stock barramundi were used as controls for fish infected in freshwater, whilst those in the main seawater tank were used as controls for barramundi infected in seawater.

Histology of barramundi organs. Moribund barramundi were killed by decapitation, dissected and the head, stomach and a sample of muscle, liver, spleen and kidney were placed in Bouin's fixative for $48 \mathrm{~h}$. After being embedded in paraffin and sectioned, the slides were stained with haematoxylin and eosin (Bucke 1989) and observed microscopically.

Virus isolation. Dead barramundi, or those killed for histological analyses, had samples from the gills, liver, spleen, kidney and dorsal muscle aseptically removed, placed in individually labelled stomacher bags, 1 to $2 \mathrm{ml} \mathrm{DMEM}$ were added and the organs were homogenized. The liquid formed was removed and clarified by centrifugation at $15000 \mathrm{rpm}$ for $15 \mathrm{~min}$. One hundred $\mathrm{ml}$ of supernatant fluid were added to BF2 cell monolayers in 24 well flat-bottomed culture plates 
(Linbro, Flow Laboratories, USA) which were incubated at $26^{\circ} \mathrm{C}$. If CPE characteristic of the Bohle iridovirus occurred (Speare \& Smith 1992) the sample was designated as BIV-infected.

\section{RESULTS}

\section{Clinical signs}

Symptoms were similar in the barramundi whether inoculated in freshwater or seawater or following bath exposure in freshwater and occurred within 1 to $3 \mathrm{~d}$ post-infection. No symptoms were observed in barramundi bath-exposed in seawater at any of the BIV concentrations employed, or in placebo-infected barramundi.

Initially, the barramundi had a reduced fright response, stopped feeding and shivered uncontrollably. More serious symptoms were observed 2 to $5 \mathrm{~d}$ post-infection. Barramundi lost the ability to orientate in the water column and lay on their sides or back. When startled, they could not move normally and would slide along the bottom of the tank. Other signs of illness included spasms, fast erratic swimming followed by long periods of inactivity and a total lack of control over body movement. As death approached, the barramundi became inactive and movement was restricted to the pectoral fins and tail with ventilation decreased and laboured. After the appearance of these symptoms, death usually resulted within 1 to $2 \mathrm{~d}$.

The majority of mortalities occurred at night. Deaths first occurred $1 \mathrm{~d}$ post-infection for fish inoculated and bath exposed in freshwater and $3 \mathrm{~d}$ post-infection for fish inoculated in seawater (Figs. 1 \& 2). The infection was most severe in seawater bath-exposed fish, even when the viral concentration was low the exception

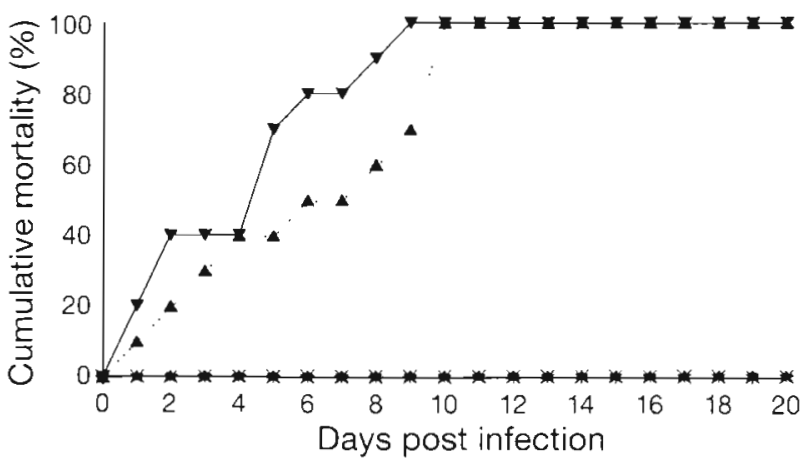

Fig. 1. Lates calcarifer. Mortality in barramundi infected with Bohle Iridovirus, held in freshwater. BIV-inoculated fish ( $\mathbf{v})$ received $0.2 \mathrm{ml}_{10}^{5} \mathrm{TCID}_{50} \mathrm{ml}^{-1}$ and bath-exposed fish (4) received $10^{3} \mathrm{TCID}_{50} \mathrm{ml}^{-1}$ for $1 \mathrm{~h}$. Ten barramundi were used for each infection regime. $(*\}$ Inoculated controls; ( $\dot{x}$ ) bath controls being barramundi bath-exposed to $10^{1} \mathrm{TCID}_{50} \mathrm{ml}^{-1}$, and although the time to initial mortalities was longer, time to total mortality occurred within a shorter period of time and no symptoms were observed (Fig. 2, Table 1).

\section{Gross findings}

External findings were limited to an ulcer at the site of injection in inoculated barramundi. An excess of fluid was evident in the peritoneal cavity. Gills were often congested. The liver had white or yellow patches on it and the spleen was enlarged. The stomachs of infected barramundi were empty.

Control barramundi, used for comparative histology, had normal gills, livers, spleens, kidneys and full stomachs. No mortalities were observed in these fish (Table 1).

\section{Histological findings}

The Bohle iridovirus infection of barramundi was characterized by focal to extensive necrosis of the haematopoietic tissue in the kidney and spleen and by tubule degeneration in the kidney. Focal necrosis was evident in the liver of several BIV-infected barramundi. No pathological changes were observed in control barramundi (Figs. 3, 6 \& 8).

\section{Kidney}

The melanomacrophage centres of the kidney were very active in infected barramundi. Liquefying necro-

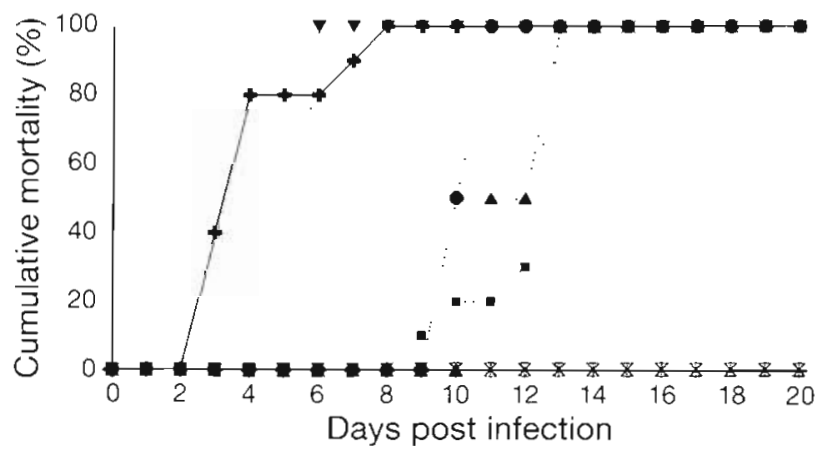

Fig. 2. Lates calcarifer. Mortality in barramundi infected with Bohle Iridovirus, held in seawater. BIV-inoculated fish received $0.2 \mathrm{ml} 10^{5} \mathrm{TCID}_{50} \mathrm{ml}^{-1}(\boldsymbol{+})$ and bath-exposed fish received $10^{3} \mathrm{TCID}_{50} \mathrm{ml}^{-1}$ for $1 \mathrm{~h}(\mathbf{\sigma})$ or $10^{2}(\mathbf{\Lambda}), 10^{1}(\mathrm{Z}), 10^{05}(\mathbf{\nabla})$ or $10^{0}(\bullet) \mathrm{TCID}_{50} \mathrm{ml}^{-1}$ for the duration of the experiment. Ten fish were used in the inoculation and bath-exposure experiment with $10^{3} \mathrm{TCID}_{50} \mathrm{ml}^{-1}$ and 4 barramundi were used for the bath-exposure experiments at the lower viral concentrations. $(+)$ Inoculated controls; $(x)$ bath controls 
Table 1. Summary of mortality, virus re-isolations and histology in BIV-infected barramundi Lates calcarifer. FW: freshwater; VI: virus inject; VB: virus bath; PI: placebo inject; PB: placebo bath; SW: seawater

\begin{tabular}{|c|c|c|c|c|}
\hline $\begin{array}{l}\text { Mode of } \\
\text { infection }\end{array}$ & $\begin{array}{l}\text { Days to first } \\
\text { symptoms }\end{array}$ & $\begin{array}{l}\text { Total } \\
\text { mortality }\end{array}$ & $\begin{array}{l}\text { BIV reisolation } \\
\text { in } B F 2 \text { cells }\end{array}$ & $\begin{array}{c}\text { BIV } \\
\text { histopathology }\end{array}$ \\
\hline FW, VI & $2-3$ & $10 / 10$ & $75 \%$ & $100 \%$ \\
\hline FW, VB $10^{3}$ & $1-2$ & $10 / 10$ & $66 \%$ & $100 \%$ \\
\hline FW, PI & No symptoms & $0 / 10$ & $0 \%$ & $0 \%$ \\
\hline FW, PB & No symptoms & $0 / 10$ & $0 \%$ & $0 \%$ \\
\hline SW, VI & $2-3$ & $10 / 10$ & $100 \%$ & $100 \%$ \\
\hline SW, VB $10^{3}$ & No symptoms & $4 / 4$ & $100 \%$ & $100 \%$ \\
\hline SW, VB $10^{2}$ & No symptoms & $4 / 4$ & $100 \%$ & $100 \%$ \\
\hline SW, VB $10^{1}$ & No symptoms & $0 / 4$ & $0 \%$ & $0 \%$ \\
\hline SW, VB $10^{0.5}$ & No symptoms & $4 / 4$ & $100 \%$ & $100 \%$ \\
\hline $\mathrm{SW}, \mathrm{VB} 10^{\circ}$ & No symptoms & $4 / 4$ & $50 \%$ & $100 \%$ \\
\hline SW, PI & No symptoms & $0 / 10$ & $0 \%$ & $0 \%$ \\
\hline$S W, P B$ & No symptoms & $0 / 10$ & $0 \%$ & $0 \%$ \\
\hline
\end{tabular}

sis ranged from focal to extensive and interstitial haemorrhage had occurred throughout the tissue. Areas of tubular epithelial cell destruction and haemorrhage into the Bowman's Capsule were evident in the mid and posterior kidney (Fig. 4). Interstitial necrosis had resulted in cellular disassociation and individual haematopoietic cells had become rounded, more dense and karyopyknotic (Fig. 5). In the severest cases, a complete lack of haematopoietic tissue was evident.

\section{Spleen}

Extensive necrosis and congestion occurred in the spleen with complete destruction of the interstitial tissue (Fig. 7). Red blood cells had degenerated and the only evidence of these cells was their pyknotic nuclei. The structure of the red and white pulp was affected and these areas could not be easily distinguished (Fig. 7). Melanomacrophage activity was greatly increased.

\section{Liver}

The liver was congested, with large areas of vacuolation. Some melanin deposition was present around the blood vessels and in some infected barramundi, focal necrosis had occurred. This necrosis usually occurred adjacent to pancreatic tissue and was always accompanied by haemorrhage (Fig 9). Liver cells became dissociated and were surrounded by cellular debris (Fig. 9). The focal necrosis in the liver was not as extensive as the necrosis in the kidney or spleen.

\section{Virus isolation from barramundi}

Bohle iridovirus was reisolated from at least one organ in all BIV-inoculated and bath-exposed barramundi, held in both seawater and freshwater, with high percentage recovery rates regardless of the viral concentration used, except for bath exposure in seawater at a concentration of $10^{1} \mathrm{TCID}_{50} \mathrm{ml}^{-1}$ where no virus was reisolated (Table 1 ). The CPE observed was typical of that produced by BIV infection of BF2 cells. No BIV was isolated from the gills of infected barramundi or from control barramundi.

Virus was most commonly isolated from the muscle and liver with homogenates from these tissues producing the earliest CPE in BF2 monolayers. Spleen and kidney homogenates also caused CPE but at a later time and at lower percentages than with the liver and muscle homogenates. After combining the positive virus isolation results for the different infection methods, the reisolations of BIV from muscle, liver, spleen and kidney were $72.7,58.8,17.7$ and $17.7 \%$, respectively.

\section{DISCUSSION}

The results reported here are the first to show that a virus isolated from a frog can produce a serious infection in a fish species. The pathology was indicative of an acute systemic infection which occurred without the appearance of external lesions. In histological preparations the only pathology was observed in the kidney and spleen, where widespread necrosis of the haematopoietic tissue had occurred (Figs, 4, 5, \& 7) and in the 

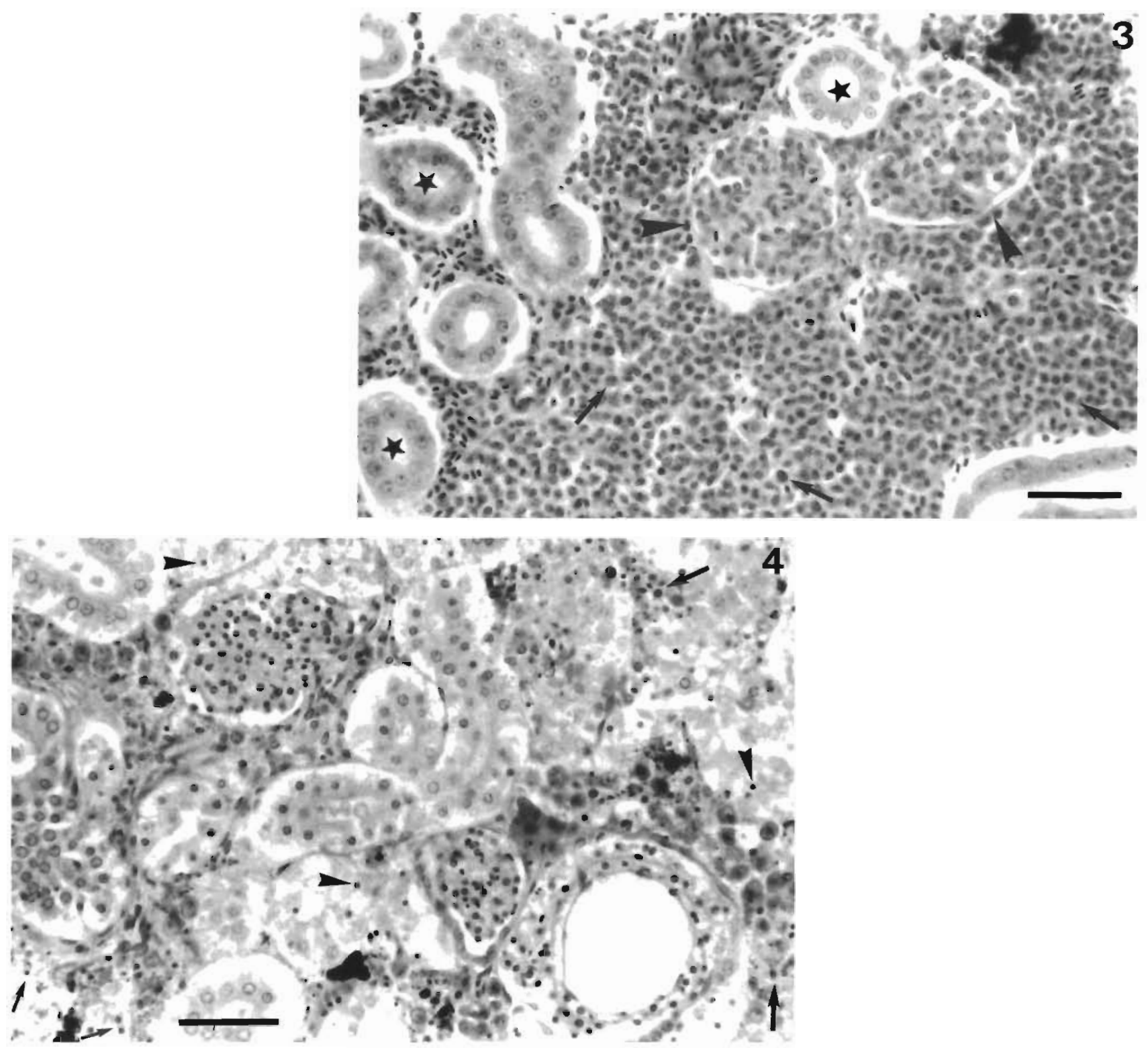

Figs. 3 to 5. Lates calcarifer. Histology of control and Bohle iridovirus-infected barramundi organs. Fig. 3. Kidney from a control barramundi. Haematopoietic cells (arrow), tubules ( $\star$ ) and glomeruli (arrowhead). H\&E $(\times 410$, scale bar $=37 \mu \mathrm{m}$ ). Figs. $4 \& 5$. Kidney from a barramundi infected with BIV showing haemorrhage (small arrow), karyopyknosis of glomerular cells and extensive necrosis, resulting in karyopyknosis and dissociation of the haematopoietic tissue (large arrow) and tubule cells (arrowhead). H\&E (Fig. 4: $\times 410$, scale bar $=37 \mu \mathrm{m}$; Fig. $5: \times 640$, scale bar $=23 \mu \mathrm{m}$ )

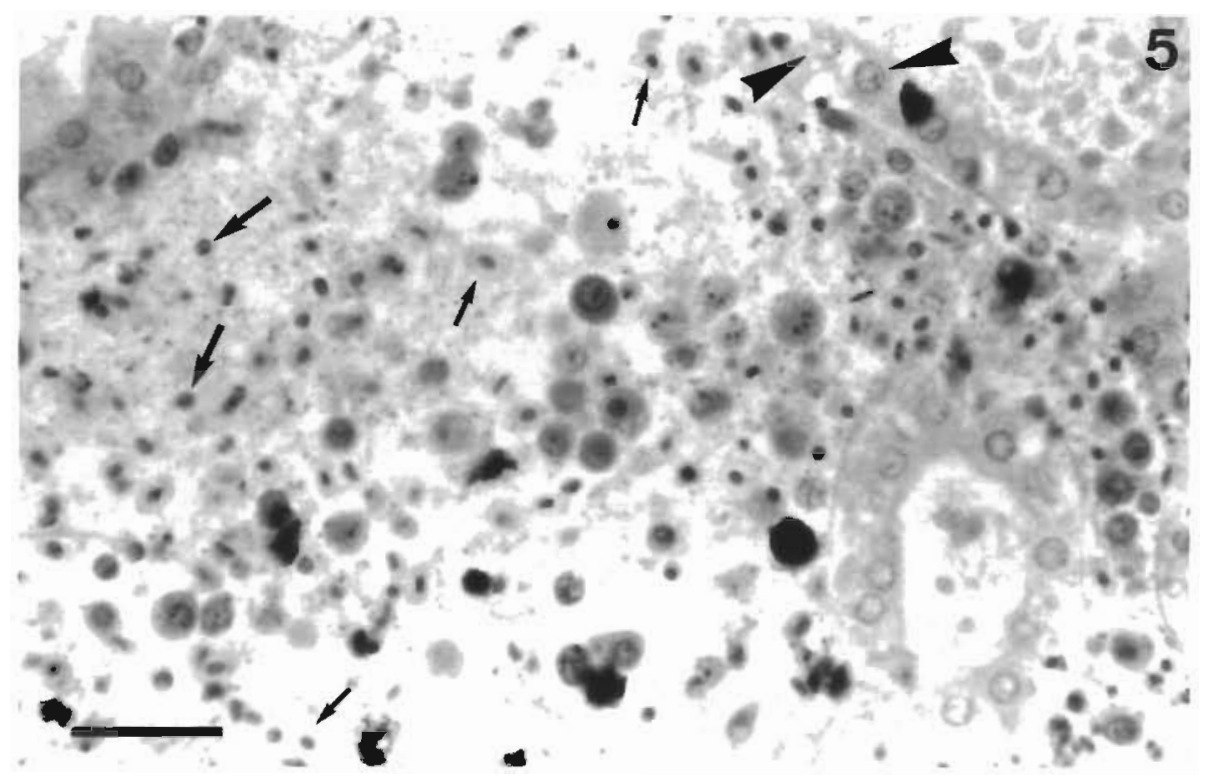



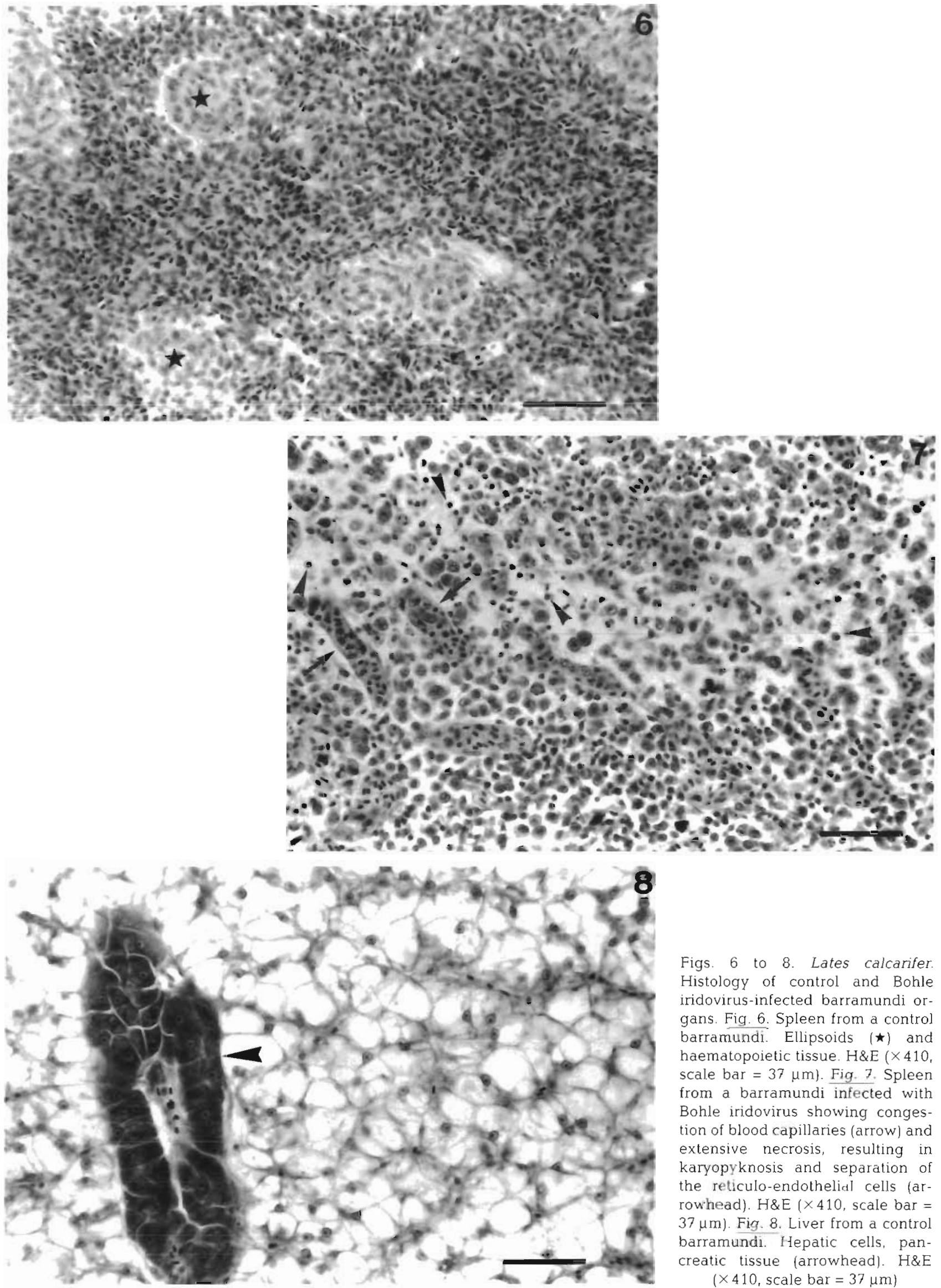

Figs. 6 to 8. Lates Calcarifer Histology of control and Bohle iridovirus-infected barramundi organs. Fic. 6. Spleen from a control barramundi. Ellipsoids ( $\star$ ) and haematopoietic tissue. $H \& E(\times 410$ scale bar $=37 \mu \mathrm{m})$. Fig. 7 . Spleen from a barramundi infected with Bohle iridovirus showing congestion of blood capillaries (arrow) and extensive necrosis, resulting in karyopyknosis and separation of the reticulo-endothelid cells (arrowhead). H\&E ( $\times 410$, scale bar $=$ $37 \mu \mathrm{ml}$. Fig. 8. Liver from a control barramundi. Hepatic cells, pancreatic tissue (arrowhead). H\&E $(\times 410$, scale bar $=37 \mu \mathrm{m})$ 
Fig. 9. Lates calcarifer. Liver of a barramundi infected with Bohle iridovirus showing liquefying necrosis, resulting in dissociated hepatic cells (arrowheads), cellular debris and haemorrhage (small arrow) occurring adjacent to pancreatic tissue (large arrow). H\&E

$(\times 410$, scale bar $=37 \mu \mathrm{m})$

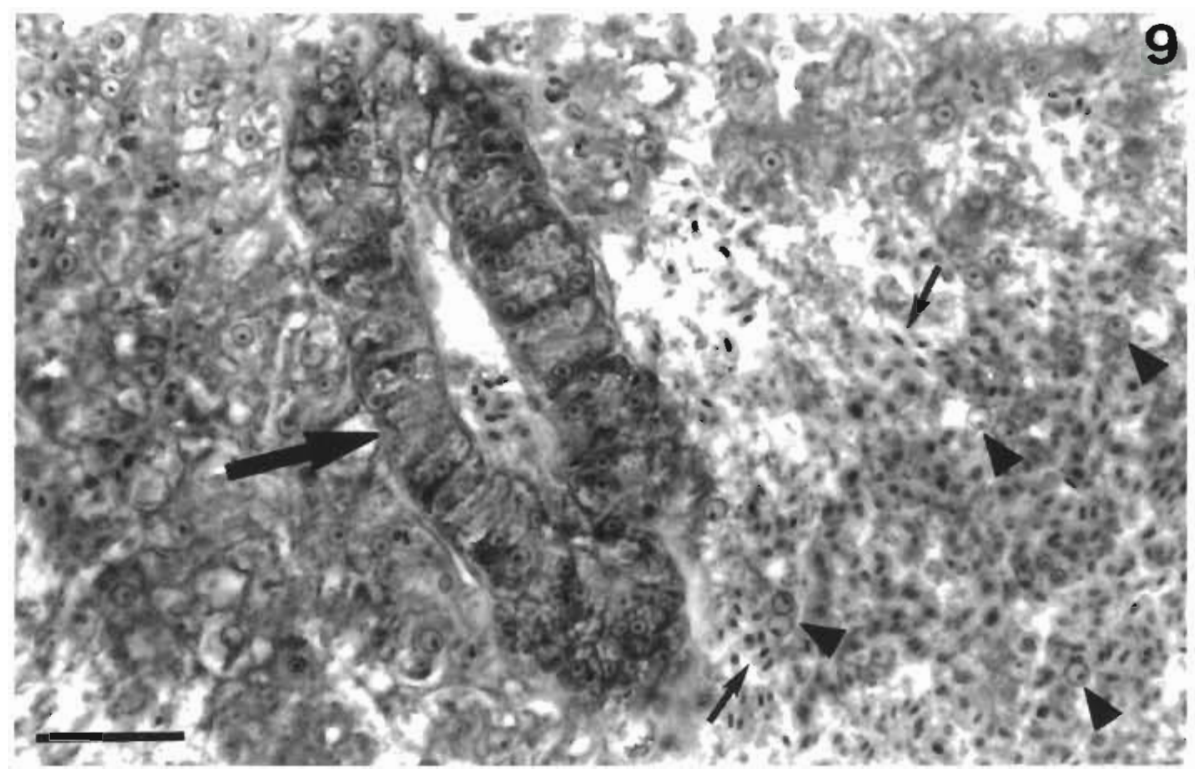

liver (Fig. 9), where focal necrosis was a common, but not consistent, observation.

The symptoms and pathology produced by BIV are similar to those produced by EHNV (Langdon et al. 1986), sheatfish iridovirus (Ahne et al. 1990) and a recently reported icosahedral deoxyribovirus of catfish Ictalurus melas (in Pozet et al. 1992). All these viruses produce serious and acute systemic infections in fish species (Hedrick et al. 1992).

In EHNV-infected redfin perch Perca fluviatilis, mortalities were as high as $100 \%$ and infected fish were listless, ataxic and often swam in a slow or rapid spiralling movement to the surface (Langdon \& Humphrey 1987). In bath infection trials, $100 \%$ mortality occurred within 4 to 5 d (Langdon 1989). EHNV-infected rainbow trout Onchorhynchus mykiss became darker in colour, ataxic and had reduced feeding. However, unlike redfin perch, mortalities in rainbow trout were only slightly higher than normal at $0.05 \% \mathrm{~d}^{-1}$ (Langdon et al. 1988). Mortalities produced by the sheatfish iridovirus were as high as $100 \%$ and in cohabitation studies, mortalities first appeared after $6 \mathrm{~d}$, with $100 \%$ mortality occurring after $11 \mathrm{~d}$. In bath exposure trials, $100 \%$ mortality was observed after $8 \mathrm{~d}$ (Ahne et al. 1990). Symptoms, which included anorexia, ataxia, apathy (Ogawa et al. 1990) and spiral swimming (Ahne et al. 1990) were similar to those observed in BIV-infected barramundi. The virus found in catfish Ictalurus melas was isolated after mass mortalities in a pond in France in 1990 (Pozet et al. 1992). In infection trials involving the catfish isolate, mortalities began 6 d post-infection and continued until Day 16 for inoculated catfish, and Day 22 for bath-exposed catfish (Pozet et al. 1992). Mortalities occurred in BIV inoculated and bath-exposed barramundi held in freshwater from 1 to $10 \mathrm{~d}$ post-infection (Fig. 1), in barramundi inoculated in seawater from 3 to $8 \mathrm{~d}$ post-infection and for barramundi bath exposed in seawater from 6 to $13 \mathrm{~d}$ post-infection (Fig. 2). One hundred percent mortality occurred in all infection regimes except bath exposure to $10^{1} \mathrm{TCID}_{50} \mathrm{ml}^{-1}$.

The pathology produced in redfin perch Perca fluviatilis (Langdon \& Humphrey 1987) and in rainbow trout Onchorhynchus mykiss by EHNV (Langdon et al. 1988) is similar to that of BIV-infected barramundi. In redfin perch, EHNV caused focal to diffuse necrosis of the renal haematopoietic tissue with variable involvement of the pancreas (Langdon \& Humphrey 1987). In rainbow trout, EHNV caused focal hepatocellular necrosis centred on an adjacent artery or vein, focal to diffuse necrosis of the splenic red and white pulp and, to a lesser extent, necrosis of the haematopoietic tissue (Langdon et al. 1988). In fish infected with the sheatfish iridovirus, almost all parenchymatous tissue showed pathological change and generalised acute necrosis of the splenic and haematopoietic tissue was the major consistent histopathological feature (Ogawa et al. 1990). Infection trials indicated the highly pathogenic nature of the viral isolate from catfish (Pozet et al. 1992). The infection was characterised by a dramatic necrotising spleno-nephritis and subsequent death of most of the fish after inoculation and bath exposure infection trials. Interstitial tissue and tubule cells were degenerated and necrotic and, in most cases, the haematopoietic structures were almost totally destroyed (Pozet et al. 1992). These pathological changes are very similar to those produced by BIV infection of barramundi (Figs. 4, 5, $7 \&$ 9) which included widespread necrosis of the haematopoietic tissue of the kidney and spleen and occasional necrosis in the liver. 
Hedrick et al. (1992) studied the viral properties of EHNV, sheatfish iridovirus and the newly discovered iridovirus-like agent in catfish. They found that these viruses shared similar morphology and size (mean diameters 153 to $154 \mathrm{~nm}$ ), common antigens (as shown by cross-immunofluorescence tests) and the number and weight of structural polypeptides for each iridovirus resembled each other and those of frog virus 3 (FV3). On the basis of size, pathogenicity and morphology, the iridovirus-like agent isolated from the catfish seemed to be more closely related to the sheatfish iridovirus and EHNV than it is to the other known piscine iridoviruses (Hedrick et al. 1992). Similarly, Hengstberger et al. (1993) reported that BIV had 12 structural proteins of similar molecular weight to those of FV3 described by Willis et al. (1977) and Elliot \& Kelly (1980). Similarities between FV3 and BIV were also found in restriction endonuclease (KpnI and HindIII) profiles of the viral DNA. These studies demonstrate a relationship between Ranavirus in amphibians and the above-mentioned systemic iridoviruses of fishes. However, Wolf et al. (1968) reported that another Ranavirus, tadpole oedema virus (TED), failed to produce an infection in experimentally infected salamanders, bluegill fry and juvenile brook and rainbow trout.

Although similarities in the symptoms and pathology produced by BIV and EHNV were found in this study, a major difference was found as well. EHNV infection experiments using barramundi did not result in the production of symptoms, pathology or mortalities (Langdon 1989); however, BIV was shown here to be highly pathogenic for barramundi. This represents another major biological difference between the two viruses, the first being that rainbow trout were refractory to BIV infection (Speare pers. comm.).

EHNV, sheatfish iridovirus and the catfish viral isolate are all known causes of epizootics and the pathological, ultrastructural and biochemical similarities which exist between BIV and these viruses indicate that Bohle iridovirus may also have the potential to cause epizootics in barramundi. This has serious implications for the barramundi aquaculture and fishing industries. The high mortality rates in freshwater and seawater, and the speed at which symptomless mortalities occur in seawater, indicates that once an infection begins, there would be little, if any, opportunity to save the infected stock. Vaccination may be the only plausible preventative measure.

Acknowledgements. The authors thank Prof. R. Speare for providing the Bohle iridovirus isolate, and Dr M. Rimmer and the Queensland Department of Primary Industries' Northern Fisheries Centre for supplying the barramundi used in these experiments. We also express our sincere gratitude to Dr J. R. Smith, Mr R. E Jones, Mr L. Reilly, Miss A. C O'Neill and Miss K. M. L. Field for their assistance and enthusiasm.

\section{LITERATURE CITED}

Ahne, W., Ogawa, M., Schlotfeldt, H. J. (1990). Fish viruses: transmission and pathogenicity of an icosahedral cytoplasmic deoxyribovirus isolated from sheatfish (Silurus glanis). J. vet. Med. B37: 187-190

Bucke, D. (1989). Histology. In: Austin, D., Austin D. A. (eds.) Methods for the microbial examination of fish and shellfish. John Wiley and Sons, New York, p. 69-94

Elliot, R. M., Kelly, D. C. (1980). Frog virus 3 replicationinduction and intracellular distribution of polypeptides in infected cells. J. gen. Virol. 37: 28-51

Hedrick, R. P., McDowell, T. S., Ahne, W., Torhy, C., de Kinkelin, P. (1992). Properties of three iridovirus-like agents associated with systemic infections in fish. Dis. aquat. Org. 13: 203-209

Ilengstberger, S. G., Ilyatt, A. D., Speare, R., Coupar, B. E. H (1993). Comparison of epizootic haematopoietic necrosis and Bohle iridoviruses, recently isolated Australian iridoviruses. Dis. aquat. Org. 15: 93-107

Langdon, J. S. (1989). Experimental transmission and pathogenicity of epizootic haematopoietic necrosis virus (EHNV) in redfin perch, Perca fluviatilis L., and 11 other teleosts. J. Fish Dis. 12: 295-310

Langdon, J. S., Humphrey, J. D. (1987). Epizootic haematopoietic necrosis: a new viral disease in redfin perch, Perca fluviatilis L., in Australia. J. Fish Dis. 10: 289-297

Langdon, J. S., Humphrey, J. D., Williams, L. M. (1988) Outbreaks of an EHNV-like iridovirus in cultured rainbow trout, Onchorhynchus mykiss Richardson, in Australia. J. Fish Dis. 11: 93-96

Langdon, J. S., Humphrey, J. D., Williams, L. M., Hyatt, A. D. Westbury, H. A. (1986). First virus isolation from Australian fish: an iridovirus-like pathogen from redfin perch, Perca fluviatilis L. J. Fish Dis. 9: 263-268

Ogawa, M., Ahne, W., Fischer-Scherl, T., Hoffman, R. W. Schlotfeldt, H. J. (1990). Pathomorphological alterations in sheatfish fry Silurus glanis experimentally infected with an iridovirus-like agent. Dis. aquat. Org. 9: 187-191

Pozet, F., Morand, M., Moussa, A., Torhy, C., de Kinkelin, P. (1992). Isolation and preliminary characterisation of a pathogenic icosahedral deoxyribovirus from the catfish Ictalurus melas. Dis. aquat. Org. 14: 35-42

Reed, L. J., Muench, H. \{1938\}. A simple method of estimating fifty percent end points. Am. J. Hyg. 27: 493-497

Speare, R., Smith, J. R. (1992). An iridovirus-like agent isolated from the ornate burrowing frog (Lymnodynastes or natus) in northern Australia. Dis. aquat. Org. 14: 51-57

Willis, D. B., Goorha, R., Miles, M., Granoff, A. (1977). Macromolecular synthesis in cells infected with frog virus 3. VII. Transcriptional and post-transcriptional regulation of virus gene expression. J. Virol. 24: 326-342

Wolf, K., Gravel, M., Malsberger, R. G. (1966). Lymphocystis virus: isolation in a centrachid fish cell line. Science 151 $1004-1005$

Wolf, K., Bullock, G. L., Dunbar, C. E., Quimby, M. C. (1968) Tadpole oedema virus: a viscerotropic pathogen for anuran amphibians. J. infect. Dis. 118: 253-262 